\title{
A COMPARATIVE STUDY ON SPORTS CARRIERS BETWEEN B.A. AND B.SC. STUDENTS
}

\section{Sunita Singh}

Sports Officers, Sudarshan Degree College, Lalgaon

ABSTRACT

AIM: The Purpose of the study was to compare the degree of Sports Carriers between B.A. \& B.Sc. students.

METHODS: The study was delimited to the thirty players (fifteen student in each discipline) who had study in Sudarshan Degree College, Lalgaon were selected randomly as the subjects for the study. The age of the subjects were ranging from $17-21$ years. The Study was further delimited to the assessment of Sports Carriers by using Factor Influencing Sports Carrier (FISC) developed by Kamlesh and Sharma. It was hypothesized that there would be no significant a difference between the B.A. \& B.Sc. students on the Sports Carriers. For the purpose of analysis of data 't' test was employed to compare the Sports Carriers between B.A. \& B.Sc. students.

RESULT: There was a significant difference between the means of B.A. \& B.Sc. students on the scores of Sports Carriers since the obtained value of ' $t$ ' (48.20) was higher than the tabulated value.

CONCLUSION: The Sports Carriers of B.A. was found to be higher than the B.Sc. students.

\section{KEYWORDS : Sports Carriers, Physical Education}

\section{INTRODUCTION}

In order to give the best possible performance at any of the competition, the assistance of scientific disciplines is sought. Induction of the basic principles of science, physical education and sports has become a subject of scientific research. Now various special branches of science such as biomechanics, physiology of exercise, psychology of sports, sociology of sports, test and measurements etc. have been established which are connected with the physical education and sports. (Indira Grandhi, 1982)

An increasing awareness is evident in games and sports in our society. Scientists from all areas are pooling their knowledge and expertise to the common cause of improving upon sports performance to an optimum level. In the quest for exhibiting top class performance, knowledge generated by science is being used to study a variety of factors that are linked either directly or indirectly. Many different aspects of the athletes are studied and emphasized during training like physical, psychological and physiological, perhaps the basis of a successful athletic performance in sports is motor ability quality of the athletes which is determined by heredity but at the same time leave a great scope for improvement, as a result of systematic supervised training. The requirements of different sports and games vary with regard to motor ability quality. Actually General Motor Ability is complex multidimentional construct due to which many factors enter into efficient performance: physical, mental, emotional, and social. (John D. Brock, Walter A. Cox and Erestus W. Pennock, 1942)

Sports psychology is the scientific study of behavior in sports or sports related context. It is an attempt to understand the how and why underlying sports behavior. (Robert A. Pestolesi and Baker Chindi)Sports psychology is defined as the study of mental processes as they relate to human sports performance. It consists of theories and laws of learning the importance of reinforcement and the linking of perceptual abilities with motor performance contribute to the body of knowledge. Sports psychologists utilize the information when studying topics such as achievement motivation, arousal, attribution and personality development.( Angela Lumpkin, 1986)

\section{METHODS}

The Purpose of the study was to compare the degree of Sports Carriers between B.A. \& B.Sc. students.

The study was delimited to the thirty players (fifteen students in each discipline) who had study in Sudarshan Degree College, Lalgaon were selected randomly as the subjects for the study. The age of the subjects were ranging from $17-21$ years. The Study was further delimited to the assessment of Sports Carriers by using Factor Influencing Sports Carrier (FISC) developed by Kamlesh and Sharma. It was hypothesized that there would be no significant a difference between the B.A. \& B.Sc. students on the Sports Carriers.

It was hypothesized that there would be no significant a difference between the B.A. \& B.Sc. students on the Sports Carriers.

\section{DESCRIPTION OF INVENTORY OF FACTOR INFLUENCING SPORTS CARRIER (FISC)}

The purpose and significance of the study were well explained and directions of answering the questionnaire were made clear to the subjects, they were politely requested to answer with utmost sincerity.

\section{PURPOSE: -}

The purpose of Factor Influencing Sports Carrier (FISC) inventory is to find out the influence of different factor on sports on sports career.

\section{PROCEDURE: -}

The FICS inventory consists of twenty items turn around internal and external factors. The allocation of different items is given in the table.

Classification of Internal and external Factor

\begin{tabular}{|c|c|}
\hline Internal Factors & External Factors \\
\hline Game superiority $(6,11,19)$ & Financial backing $(5,12)$ \\
\hline Practice $(4,16,20)$ & Equipment and coaching $(9,15)$ \\
\hline Ability $(1,10,17,18)$ & Luck $(2,7,13)$ \\
\hline & High Ups $(3,8$ and 14) \\
\hline
\end{tabular}

The subject response to each items using a five point ordinal scale. Every statement has three possible responses i.e.:-SD (Strongly Disagree) 0, D (Disagree) 1, U (Undecided) 2, A (Agree) 3, SA (Strongly Agree) 4.

\section{THE EXAMPLES OF FISC INVENTORY ARE FOLLOWING:}

1. Whether or not I am selected to be a member of National/State/University team depends up my ability to play the game.

2. To a great extent, my sports career is controlled by accidental happenings. 
SCORING:

The response sheet score in accordance with the response intensity key. Responses to two seats of factors will summate separately. Thus, in each case two summate score will obtain.

Categorization of Sportsmen According to Dependence upon Internal and External factors

\begin{tabular}{|l|l|l|}
\hline Dependence & Internal Factors & External Factors \\
\hline Extreme & 33 or above & 25 or above \\
\hline Moderate & Around 30 & Around 17 \\
\hline Poor & 27 or below & 15 or below \\
\hline
\end{tabular}

For the purpose of analysis of data 't' test was employed to com pare the degree of Sports Carriers between B.A. \& B.Sc. students.

\section{FINDINGS}

TABLE -1 SIGNIFICANT DIFFERENCE OF MEAN ON SPORTS CARRIERS BETWEEN B.A. AND B.SC. STUDENTS

\begin{tabular}{|l|l|l|l|l|l|l|l|}
\hline Variable & \multicolumn{2}{|l|}{ Mean } & S.D & Mean Diff. & S.E Diff & t-Ratio \\
\cline { 2 - 5 } & B.A. Students & B.Sc. Students & B.A. Students & B.Sc. Students & & & \\
\hline Sports Carriers & 42.90 & 41.70 & 5.26 & 2.58 & 1.20 & 1.852 & $2.585^{*}$ \\
\hline
\end{tabular}

${ }^{*}$ Significant at .05 level of confidence

$\mathrm{t}_{.05}(28)=2.048$

It is evident from Table-l that there was a significant difference between the means of the B.A. \& B.Sc. students on the Sports Carriers since the obtained value of ' $t$ ' $\left(2.585^{*}\right)$ was higher than the tabulated value of ' $t$ ' (2.048) which was required to be significant at (28) degree of freedom with 0.05 level of confidence.

The graphical representation of mean and standard deviation of Sports Carriers between B.A. \& B.Sc. students has been presented in figure 1.

\section{SPORTS CARRIERS}

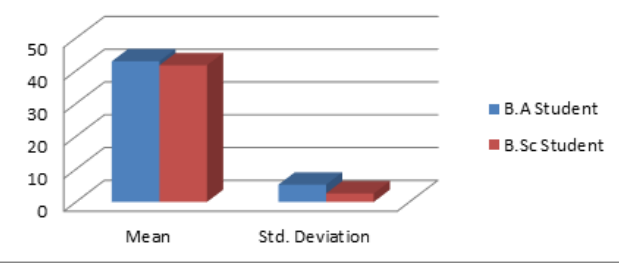

Figure 1-Comparison of Mean Scores between B.A. \& B.Sc. Students on Sports Carriers

\section{DISCUSSION OF FINDINGS}

The mean value (43.27) of B.A. students on Sports Carriers was found to be higher than the B.Sc. students, which revealed that B.A. students were more Sports Carriers in comparison to the B.Sc. students.

The Factor Influencing Sports Career inventory developed by Kamlesh and Sharma is to find out the influence of different internal and external factor on sports career. They suggest, if sportsperson influences highly with internal factor influencing sports career i.e. game superiority, practice and ability perform excellent in compare to those sportsperson who have high influenced with external factor influencing sports career i.e. by financial banking, equipment and coaching, luck and high ups.

\section{DISCUSSION OF HYPOTHESIS}

The hypothesis that there will be a no significant difference between the B.A. \& B.Sc. students on the Sports Carriers is rejected.

\section{CONCLUSIONS}

1. In regard to Sports Carriers there was a significant diffe rence between the means of B.A. \& B.Sc. students.

2. The Sports Carriers level of B.A. students was found to be higher than the B.Sc. students.

\section{REFERENCE:}

1. Angela Lumpkin, "Physical Education: A Contemporary Introduction" (Saint Louis: Times Mirror/Mosby College Publishing, 1986), pp.51-52.

2. Brayanat J.Cratty, Psychology in Contemporary Sport, Guidelines for Coaches and Athletes (U.S.A.: Englewood Cliffs, 1983), P 106.

3. Cal E. Kalfs and Caniel D.Arutheim. Modern Principles of Athletics Training (St.Louis: C.V.Mosby Company, 1969), p.117.

4. Indira Grandhi, "Message" Abstracts : International Congress of Sports Science (Patiala: Netaji Subhash National Institute of Sport, November, 1982).

5. John D. Brock, Walter A. Cox and Erestus W. Pennock, "Motor Fitness", Research Quarterly Vol. 12, No.2, May 1941.

6. Mahoney J.M. and Avener, K., "Psychology of the Elite Athlete," An Exploratory Study, Cognitive Therapy and Research 1 (1977).

7. Robert A. Pestolesi and Baker Chindi, "Introduction to Physical Education: A Contemporary Careers Approach" 2nd ed., p-145.

8. Vealy, S.R. "Conceptualization of Sports Confidence \& Competitive Orientation," Journal of Sports Psychology 8 (1986). 